\title{
Antineoplastic activity of a methanolic extract from Kigelia pinnata DC stem bark
}

Denitsa Momekova ${ }^{1}$, Georgi Momekov ${ }^{2 *}$, Ivanka Pencheva ${ }^{3}$ and Spiro Konstantinov ${ }^{2}$

Correspondence: gmomekov@cetrh.org

${ }^{1}$ Department of Pharmaceutical Technology and Biopharmaceutics, Faculty of Pharmacy, Medical University-Sofia, Dunav Str., 1000 Sofia Bulgaria.

${ }^{2}$ Lab of Experimental Chemotherapy, Department of Pharmacology, Pharmacotherapy and Toxicology,

Faculty of Pharmacy, Medical University-Sofia, 2 Dunav Str., 1000 Sofia Bulgaria;

${ }^{3}$ Department of Pharmaceutical Chemistry, Faculty of Pharmacy, Medical University-Sofia, 2 Dunav Str., 1000 Sofia Bulgaria.

\begin{abstract}
Background: The study was aimed to assess the antineoplastic activity of a total methanolic extract (TME) from the stem bark of Kigelia pinnata - an African medicinal plant with well-documented ethnopharmacological use.

Methods: The in vitro testing included cytotoxicity (MTT assay) and pro-apoptotic activity investigation. The antineoplastic activity of TME was investigated in Lewis lung carcinoma (LLC) bearing BDF-1 mice.

Results: TME displayed prominent cytotoxicity against a panel of human tumor cell lines. TME evoked DNA laddering in SKW-3 cells, indicative for induction of apoptosis. TME exerted strong antineoplastic activity against LLC with prominent increase of the life span of treated animals and tumor growth inhibition.

Conclusion: On the basis of the in vitro studies and the observed in vivo antineoplastic potential of the plant it could be concluded that there is enormous scope for future investigations on K. africana as a source of potential anticancer agents.
\end{abstract}

Keywords: Kigelia africana, plant extracts, MTT-assay, cell lines, cytotoxicity, apoptosis, Lewis lung carcinoma.

\section{Background}

At present plant-derived cytotoxic drugs (e.g. the Vinca alkaloids, epipodophyllotoxins, camptothecins and taxanes) play a key role in antineoplastic drug therapy and a number of other phytochemicals are subjected to clinical trials [1-6]. Moreover, the unfavorable safety profile of existing chemotherapeutics and the issue of drug resistance have fuelled the search for novel plant compounds as potential anti-cancer agents $[7,8]$. In addition to the systematic large-scale screening of unexplored plant species [9] and the phytochemically-guided search of molecules which are structurally related to established antineoplastic drugs [10], the other possible approach for identifying perspective drug candidates is based on ethnopharmacology, i.e. scientific study of traditional plant remedies $[7,11]$. Such studies have received further impact due to introduction of high-throughput screening techniques and improved methods for extraction, isolation and structural elucidation of biologically active compounds $[4-6,9,12]$. In recent years ethnopharmacological studies of extracts or pure compounds from medicinal plants have provided considerable justification for their traditional use to treat neoplastic diseases $[\mathbf{7 , 8 , 1 1 ]}$.

Kigelia pinnata DC (or K. africana, Bignoniaceae family), also known as Sausage Tree, or Worsboom, in view to its bulky, characteristically shaped fruits, has a variety of traditional medicinal uses throughout Africa where it grows as an endemic species in different habitats $[13,14]$, as well as in India and the Middle East whereby the tree has been widely cultivated $[15,16]$. The extensive phytochemical examinations of the plant has resulted in the isolation of different secondary metabolites such as iridoids [17-19] and naphtoquinoids [20-24], considered to convey much of its pharmacological activities [13], although flavonoids, lignans, terpenoids, coumarins, phenylethanoids, phenylpropanoids and sterols have been isolated, as well $[14,24,25]$.

Much of the studies on the biological activity of Kigelia pinnata have been concentrated on its antimicrobial effects $[\mathbf{1 7}, \mathbf{2 4}]$ and its cytotoxicity against cancer cell lines [20-22]. This research interest is related to the traditional uses of bark and fruit extracts throughout Africa as remedies for treating sexually transmitted diseases, dysentery, leprosy, miscellaneous microbial and parasitic infections, skin ulcers, and neoplastic diseases $[\mathbf{1 3}, \mathbf{1 4}, \mathbf{1 6}, \mathbf{2 6}]$. Moreover, extracts from the plant, as well as isolated compounds, have been found to exert a constellation of other pharmacological effects, including antifungal [24], antiprotozoal (against Trypanosoma brucei brucei, Trypanosoma brucei rhodesiense [23], and several, including

(C) 2012 G. Momekov et al; licensee Herbert Publications Ltd. This is an open access article distributed under the terms of Creative Commons Attribution License (http://creativecommons.org/licenses/by/3.0), This permits unrestricted use, distribution, and reproduction in any medium, provided the original work is properly cited. 
multi-drug resistant, strains of Plasmodium falciparum [27-29]), antiinflammatory and analgesic [15,19], hepatoprotective [30], anti-fertility [31], CNS-stimulant, antidiarrheal, and antidiabetic $[13,14,32]$, among others.

Pharmacological studies regarding the antineoplastic potential of the plant were fuelled by anecdotal reports for the traditional use of fruit and stem bark extracts by indigenous Africans and by white settlers for the treatment of melanoma and other skin neoplasms [13], as well as for the management of endometrial cancer [14], and hence much of the experimental chemotherapy research was focused on solid tumor-derived cell lines [20-22,33]. Studies were initiated testing ethanol and dichloromethane extracts from Kigelia pinnata fruit and stem bark for cytotoxicity against melanoma and renal carcinoma derived cell lines [20-22]. By means of bioactivity-guided fractionation it has been found that the extracts contain various cytotoxic agents, such as lapachol (regarded as a potential anti-cancer drugs) [34,35], norviburtinal [22], kigelinone, and $\gamma$-sitosterol [16] among others. Nevertheless, the relative contribution of every different compound to the observed activity of the extracts remains elusive, because some of these (e.g. norviburtinal and lapachol) are present in the plant materials at very low concentration to be main responsible anti-cancer constituents, while the cytotoxicity of others, such as $\gamma$-sitosterol has remained an issue of debate $[13,14,22]$.

Considering the scarce data about the efficacy of Kigelia pinnata against hematological malignancies and the lack of evidence for in vivo antineoplastic activity in the available literature we sought to determine the anticancer potential of a stem bark methanolic extract in a panel of human tumor cell lines, including leukemia and lymphoma derived cells, and to evaluate its efficacy against Lewis lung carcinoma, transplanted s.c. in BDF-1 mice, in terms of tumor growth inhibition and increase in life span.

\section{Methods}

Drugs, chemicals and reagents. Formic acid, 2-propanol, L-glutamine and ethidium bromide were purchased from AppliChem GmbH, Darmstadt, Germany. Fetal calf serum (FCS) and RPMI 1640 medium were purchased from Sigma - Aldrich Co., the USA. The tetrazolium salt 3-(4,5-dimethylthiazol-2-yl)2,5-diphenyl tetrazolium bromide (MTT) was supplied from Merck Co., Germany. The referent antineoplastic drug vincristine was used as a commercially available sterile dosage form for clinical application.

Plant material, extract preparation, fractionation and formulation. Dried Kigelia pinnata stem bark was supplied from a licensed Nigerian wholesaler with the kind assistance of Mr. A.-H. T. Sahninna. The plant material was identified by Asst. Prof. P. Nedialkov and Asst. Prof. D. Zheleva and a voucher specimen was deposited at the Herbarium of the Dept. of Pharmacognosy and Pharmaceutical Botany at the Faculty of Pharmacy (MU-Sofia) (No 17/2010). The powdered
$(1 \mathrm{~mm})$ stem bark was refluxed with methanol (1: 20) for $1 \mathrm{~h}$ at $80^{\circ} \mathrm{C}$. After cooling at room temperature the extract was filtered and the residue was subject to the same extraction process twice. Thereafter the filtrates were gathered and the solvent was evaporated in vacuo to dryness. The so prepared total methanolic extract (TME) was either used for the pharmacological studies or subjected to column chromatography fractionation.

For further processing of the so prepared total extract (for the bioactivity guided fractionation) it was dissolved in $\mathrm{MeOH}$ $(1: 3)$ and mixed with 1.0 Silicagel prior to chromatographic assay. Equal quantities were subject to column chromatography, under the following conditions - column with $50 \mathrm{~cm}$ length and $1 \mathrm{~cm}$ diameter using Silicagel as adsorbent and the following mobile phases: (i) chloroform; (ii) chloroform : ethyl acetate (1:1); (iii) methanol : ethyl acetate (2:8); (iv) methanol : ethyl acetate (1:1); (v) methanol : ethyl acetate (8:2); (vi) methanol. The eluates were chromatographed on pre-coated plates of kieselgel $\mathrm{G}_{60} \mathrm{~F}_{254}$ using the following mobile phases for developing the chromatograms: (i) $20 \%$ ethyl acetate in cyclohexane; (ii) petroleum ether: acetone: chloroform; methanol (4:1.5:4:0.5); (iii) 50\% ethylacetate in cyclohexane. The solvents were evaporated in a warm air stream and detection was with UV light at 254 and $366 \mathrm{~nm}$. Based on the chromatographic analysis eluates were combined in 10 pooled fractions, and thereafter the solvent was removed with a rotary evaporator. The TLC plates were also analyzed for the presence of quinone derivatives using $10 \% \mathrm{KOH}$ methanolic solution as a spray reagent [36].

For the in vitro bioassay the extracts were freshly dissolved in DMSO and thereafter promptly diluted with RPMI-1640 medium to yield the desired working concentrations. For the in vivo experiments the total methanolic extract was freshly dissolved in sterile saline at $36^{\circ} \mathrm{C}$ in a thermostat-supplemented bath-type sonicator.

Cell lines and culture conditions. The study was carried out with the following cell lines: (i) SKW-3 (ACC 53) - human T-cell leukemia, originally described to be established from the peripheral blood of a 61-year-old man with T cell chronic lymphocytic leukemia (CLL) in 1977; however, DNA fingerprinting and cytogenetic analysis showed crosscontamination with cell line KE-37; KE-37 was established from a 27-year-old man with acute lymphoblastic leukemia (ALL) in 1979; (ii) REH (ACC 22) - human B-cell precursor leukemia, established from the peripheral blood of a 15 -year-old North African girl with acute lymphoblastic leukemia (ALL at first relapse) in 1973; carries $t(12 ; 21)$ leading to ETV6-RUNX1 (TELAML1) fusion gene; (iii) HL-60 (ACC 3) - human acute myeloid leukemia (AML), established from the peripheral blood of a 35-year-old woman with acute myeloid leukemia (AML FAB M2) in 1976; cells are apparently tetraploid derivates of the hypodiploid original; (iv) K-562 (ACC 10) - human chronic myeloid leukemia (CML) established from the pleural effusion of a 53-year-old woman with CML in blast crisis in 1970; cells 
carry the BCR-ABL1 e14-a2 (b3-a2) fusion gene; the used subclone weakly expresses MHC class I (image); (v) DOHH-2 (ACC 47) - human non-Hodgkin lymphoma, established from the pleural effusion of a 60-year-old man with refractory immunoblastic B cell lymphoma progressed from follicular centroblastic/ centrocytic lymphoma in 1990; cells were described to carry the $t(14 ; 18)$ leading to IGH-BCL2 fusion gene and to express BCL2 mRNA; the original culture has been a mixture of EBV - and EBV + cells, of which the EBV cells were isolated and clonally expanded; (vi) HD-MY-Z (ACC 346) human Hodgkin lymphoma, established in 1991 from the pleural effusion (rich in Hodgkin/Reed-Sternberg cells) from a 29-year-old patient with nodular sclerosing Hodgkin lymphoma (stage IIlb) refractory to therapy; (vii) MCF-7 (ACC 115) - human adenocarcinoma, established from the pleural effusion of a 69-year-old Caucasian woman with metastatic mammary carcinoma (after radio- and hormone therapy) in 1970; cells were described of being positive for cytoplasmic estrogen receptors and having the capability to form domes. The cell lines were obtained from the German Collection of Microorganisms and Cell Cultures (DSMZ GmbH, Braunschweig, Germany). They were cultured under standard conditions - RPMI-1640 liquid medium supplemented with 10\% fetal bovine serum (FBS) and $2 \mathrm{mM} \mathrm{L-glutamine,} \mathrm{in} \mathrm{cell} \mathrm{culture} \mathrm{flasks,}$ housed at $37^{\circ} \mathrm{C}$ in an incubator 'BB 16-Function Line' Heraeus (Kendro, Hanau, Germany) with humidified atmosphere and $5 \% \mathrm{CO}_{2}$. Cell cultures were maintained in logarithmic growth phase by supplementation with fresh medium two or three times weekly.

Cytotoxicity assessment (MTT-dye reduction assay). The cell viability after exposure to the tested compounds was assessed using the MTT-dye reduction assay, based on the biotransformation of the yellow dye 3-(4,5-dimethylthiazol-2-yl)2,5-diphenyl tetrazolium bromide to a violet formazan product via the mitochondrial succinate dehydrogenase in viable cells. The procedure was carried out as described elsewhere [37], with some modifications [38]. Exponentially growing cells were seeded in 96-well flat-bottomed microplates $(100 \mu \mathrm{l} /$ well $)$ at a density of $1 \times 10^{5}$ cells per $\mathrm{ml}$ and after a $24 \mathrm{~h}$ incubation period at $37^{\circ} \mathrm{C}$ they were treated with graded concentrations of the extract (or its fractions) for $72 \mathrm{~h}$. For each concentration a set of 8 wells was used. After the exposure period 10 $\mu$ I MTT solution $(10 \mathrm{mg} / \mathrm{ml}$ in PBS) aliquots were added to each well. The microplates were further incubated for $4 \mathrm{~h}$ at $37^{\circ} \mathrm{C}$ and the MTT-formazan crystals formed were dissolved through addition of $100 \mu \mathrm{l} /$ well $5 \%$ formic acid in 2-propanol. The MTTformazan absorption was determined using a microprocessor controlled microplate reader (Labexim LMR-1) at $580 \mathrm{~nm}$.

Apoptosis assay. Oligonucleosomal DNA fragments were isolated from the cytosolic fraction of SKW-3 cells (untreated controls, and treated with Kigelia pinnata stem bark total methanolic extract or vincristine for $24 \mathrm{~h}$ ) and analysed by gel electrophoresis as previously described [38]. Briefly, exponentially growing SKW-3 cells were exposed to varying concentrations of the tested compounds and after the treatment period the cells were pelleted and washed thrice in PBS. Thereafter the cell pellets were resuspended in $0.25 \mathrm{ml} \mathrm{PBS}$ and lysed through addition of $0.5 \mathrm{ml}$ lysis buffer ( $0.5 \%$ Triton X-100, $20 \mathrm{mM}$ Tris $\mathrm{HCl}, 1 \mathrm{mM}$ EDTA, $\mathrm{pH}=7.4$ ). After centrifugation (13000 rpm for $20 \mathrm{~min}$ ) the supernatants were transferred into Eppendrof safe lock tubes. DNA was precipitated by addition of $0.187 \mathrm{ml} 6 \mathrm{M} \mathrm{NaCl}$ solution and 0.937 $\mathrm{ml}$ 2-propanol. After mixing the samples were incubated at $-20^{\circ} \mathrm{C}$ overnight and subsequently were spun at $13000 \mathrm{rpm}$ for $20 \mathrm{~min}$. DNA precipitates were then washed with $1 \mathrm{ml}$ $70 \%$ ethanol. The DNA pellets were air dried and dissolved in $20 \mu \mathrm{l}$ distilled water. The samples were analysed by $0.8 \%$ agarose gel electrophoresis and visualized by ethidium bromide staining under UV light. The DNA laddering was documented using an integrated UV-trans-illuminator with a fixed CCD camera (UVBioDoc-It ${ }^{\text {TM }}$ System, al-Biotech GmbH, Martinsried, Germany).

Bioassay data processing and statistics. The cell survival data were normalized as percentage of the untreated control (set as $100 \%$ viability), were fitted to sigmoidal dose response curves and the corresponding $\mathrm{IC}_{50}$ values (concentrations causing $50 \%$ suppression of cellular viability) were calculated using non-linear regression analysis (GraphPad Prizm Software for $P C)$. The statistical processing of biological data included the Student's t-test whereby values of $p \leq 0.05$ were considered as statistically significant. The in vivo data development is described in the corresponding section of the Materials and methods section.

In vivo studies (experimental design, treatment and assessment of the antineoplastic activity). Animal studies were approved by the Institutional Ethics and Animal Care Committee. Young adult male C57BL/ 6 and BDF- 1 mice of 6 to 8 weeks old, weighing $21 \pm 2 \mathrm{~g}$ were purchased from the National Breeding Centre (Slivnitza, Bulgaria). Animals were housed in the Animal Care Facility of the Faculty of Pharmacy, MU-Sofia with free access to water and standard pelleted food (Altromin Spezialfutter GmbH \& Ko KG, Germany) with $12 \mathrm{~h}$ alternating light/dark cycles. The in vivo studies were carried out as described elsewhere [39]. In brief, Lewis Lung Carcinoma originally obtained from the Lab of Oncopharmacology at the National Oncological Hospital (Sofia Bulgaria), has been maintained in our facility by serial passages subcutaneously (s.c.) in inbred C57BL/6 mice since 1994. The tumor mass (2-3 $\mathrm{g}, 3-4$ weeks old) was minced in $10 \mathrm{~mL}$ Hank's solution and filtered through an 80-mesh screen with a 21-gauge needle. An aliquot $(0.2 \mathrm{~mL})$ of the tumor homogenate containing $2-4 \times 10^{5}$ viable tumor cells was inoculated subcutaneously (s.c.) into male BDF-1 mice, in the right flank. Mice were randomly divided into 4 groups (10 mice per group) as follows: (i) normal saline - treated control group; (ii) Kigelia pinnata stem bark methanolic extract $37.5 \mathrm{mg} / \mathrm{kg}$ (i.p.; $\times 3$ ); (iii) Kigelia pinnata stem bark methanolic extract $75 \mathrm{mg} / \mathrm{kg}$ (i.p. $\times 3$ ); and (iv) Kigelia pinnata stem bark methanolic extract $105 \mathrm{mg} / \mathrm{kg}$ 
(i.p.; $\times 3$ ). Treatment was performed on days $1^{\text {st }}, 5^{\text {th }}$ and $9^{\text {th }}$ post transplantation. Tumor size was determined by caliper measurement of the largest and perpendicular diameters on study days 6,10 and 14 . Tumor volume was calculated according to the formula $V=0.52 . a \cdot b^{2}$ ( $a$ is the largest superficial diameter and $b$ is the smallest superficial diameter). The tumor growth inhibition (TGI\%) was calculated using the following formula: $\left.\mathrm{TGI}(\%)=\left(\left(\mathrm{V}_{\mathrm{T}}-\mathrm{V}_{\mathrm{c}}\right) / \mathrm{V}_{\mathrm{c}}\right)\right) .100$, where $\mathrm{V}_{\mathrm{T}}$ is the mean tumor volume in the treatment group and $V_{C}$ is that of the control mice. The survival of animals was monitored on daily basis until the completion of the experiment. Thereafter, Kaplan-Meier curves were generated and the median survival times were calculated using GraphPad Prizm software. Improvement in survival was evaluated as follows: ILS $\%=((T / C)-1) \times 100$, where ILS is the increase in life span, $C$ is the median survival days of the control mice and $\mathrm{T}$ is that of the treated mice. According to $\mathrm{NCl}$ criteria ILS $>25 \%$ was set as threshold for activity, whereas treatment yielding ILS $>50 \%$ was considered highly active [40].

\section{Results}

The cytotoxic effects of $K$. pinnata stem bark total methanolic extract were evaluated in a panel of human tumor cell lines representative for some important neoplastic diseases namely acute lymphoid leukemia (SKW-3 and REH), acute myeloid leukemia (HL-60), chronic myeloid leukemia (K-562), B-cell lymphoma (DOHH-2), Hodgkin lymphoma (HD-MY-Z), ERpositive breast cancer (MCF-7) and murine lung cancer (Lewis lung cell line). In addition, the initial total extract was further subjected to a bioactivity guided fractionation (see below). The equieffective $I C_{50}$ concentrations (the concentration leading to $50 \%$ reduction of the cellular viability) served as criteria for comparing the cytotoxic activity of the extract and its fractions. Throughout the cytotoxicity screening the clinically applied anticancer drug vincristine was employed as a positive control.

Bioassay results of the total methanolic extract of Kigelia pinnata stem bark are summarized on Table 1. Evident from the results obtained, the tested total extract displayed prominent cytotoxic activity in a concentration-dependent manner. The cell lines with most pronounced chemosensitivity to the extract were the breast cancer derived MCF-7, the murine Lewis lung cancer (cell line) and the acute T-cell leukemia SKW-3, whereby the $\mathrm{IC}_{50}$ values were significantly lower as compared to those obtained in the other cell lines.

A bioactivity-guided fractionation of the parent extract using SKW-3 cells as tumor test system was undertaken
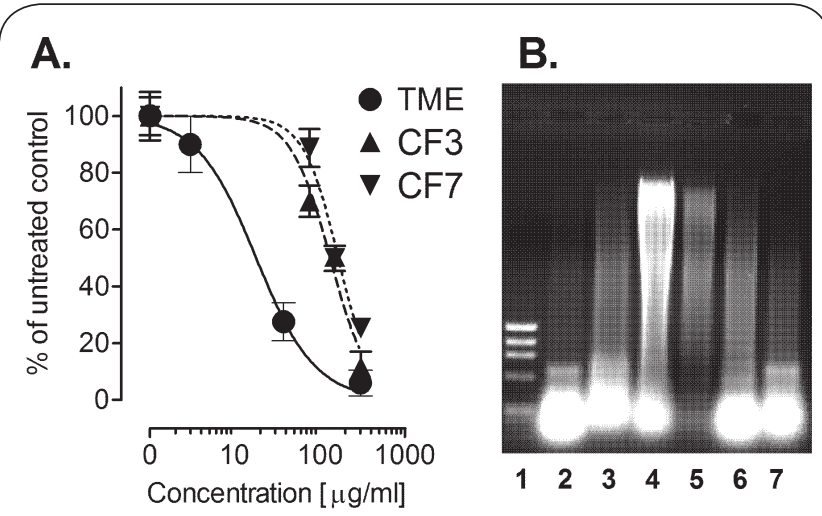

Figure 1. A. Cytotoxic effects of Kigelia pinnata stem bark (total methanolic extract (TME) and chloroform fractions CF3 and CF7) against SKW-3 cells after $72 \mathrm{~h}$ treatment. Each data point represents the arithmetic mean \pm sd of eight separate experiments. B. DNA-laddering of the genomic DNA extracted from SKW-37 cells after exposure to Kigelia pinnata stem bark TME as assessed by $0.8 \%$ agarose gel electrophoresis, ethidium bromide staining and UV-transillumination. (1) DNA fragmentation marker; (2) untreated control; (3) Kigelia pinnata TME $300 \mu \mathrm{g} / \mathrm{ml}$; (4) Kigelia pinnata TME 150 $\mu \mathrm{g} / \mathrm{ml}$; (5) Kigelia pinnata TME $75 \mu \mathrm{g} / \mathrm{ml}$; (6) vincristine 0.5 $\mu \mathrm{g} / \mathrm{ml}$; (7) vincristine $1 \mu \mathrm{g} / \mathrm{ml}$.

Table 1. Bioassay data regarding the cytotoxicity of Kigelia pinnata stem bark methanolic extract in a panel of human tumor cell lines. The equieffective IC50 concentrations were calculated from the experimental bioassay data using non-linear regression analysis (GraphPad Prizm software).

\begin{tabular}{|c|c|c|c|c|c|c|c|c|}
\hline \multirow{2}{*}{ Treatment } & \multicolumn{8}{|l|}{ IC50 ( $\mathrm{gg} / \mathrm{ml})$} \\
\hline & SKW-3 ${ }^{a}$ & $\operatorname{Reh}^{\mathrm{b}}$ & HL-60' & $K-562^{d}$ & DOHH-2 & HD-MY-Z & MCF-7g & LL $^{\mathrm{h}}$ \\
\hline TME & $15.1 \pm 3.4$ & $126.0 \pm 9.1$ & $90.7 \pm 4.7$ & $186.0 \pm 9.2$ & $101.0 \pm 7.4$ & $124.1 \pm 8.9$ & $11.8 \pm 3.8$ & $10.2 \pm 2.7$ \\
\hline CF3 & $148.1 \pm 7.5$ & n.d. & n.d. & n.d. & n.d. & n.d. & n.d. & n.d. \\
\hline CF7 & $150.6 \pm 3.4$ & n.d. & n.d. & n.d. & n.d. & n.d. & n.d. & n.d. \\
\hline Vincristine* & $0.22 \pm 0.1$ & $3.3 \pm 0.9$ & $1.5 \pm 0.7$ & $4.1 \pm 1.4$ & $1.2 \pm 0.6$ & $7.4 \pm 1.0$ & $3.7 \pm 0.6$ & $2.2 \pm 0.4$ \\
\hline
\end{tabular}

${ }^{\mathrm{a}}$ T-cell leukemia (a KE-37 derivative), bacute lymphoid leukemia, ${ }^{\mathrm{c}}$ acute myeloid leukemia, ${ }^{\mathrm{d}} \mathrm{chronic}$ myeloid leukemia, ${ }^{\mathrm{e}}$ non-Hodgkin lymphoma, ${ }^{\mathrm{f} H o d g k i n}$ lymphoma, ${ }^{\mathrm{g}}$ breast cancer; ${ }^{\mathrm{h}}$ Lewis lung cell line - murine lung cancer; ${ }^{\star}$ positive control. 

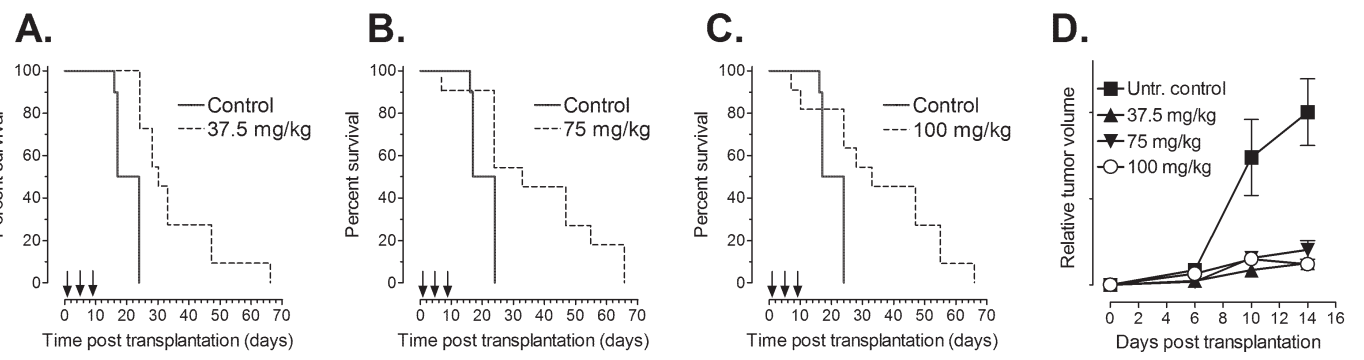

Figure 2. Antineoplastic activity of Kigelia pinnata stem bark total methanolic extract (TME) in Lewis lung carcinoma-bearing BDF-1 mice. The extract was applied at doses of 37.5, 75 and $100 \mathrm{mg} / \mathrm{kg}$, i.p. on study days 1,5, and 9 (as indicated by the arrows). A.-C. Kaplan Meier survival curves for treated mice vs. saline-treated controls. D. Effects of TME on the relative tumor volume assessed on days 6th, 10th and 14th, post transplantation.

Table 2. In vivo antineoplastic activity of Kigelia pinnata stem bark methanolic extract against Lewis lung carcinoma, transplanted s.c. in BDF-1 mice as assessed by the increase in life span (ILS \%) and tumor growth inhibition (TGI\%) endpoints.

\begin{tabular}{lcccccc}
\hline Experimental group & MST & T/C \% & ILS (\%) & $\begin{array}{c}\text { Long term } \\
\text { survivors1 }\end{array}$ & \multicolumn{2}{c}{ TGI (\%) } \\
& & & & 10 & th Day & 14 ${ }^{\text {th }}$ Day \\
\hline Control (saline $\times 3)$ & 20.4 & N/A & N/A & 0 & N/A & N/A \\
TME 37.5 mg/kg i.p. $(\times 3)$ & $30.2^{* *}$ & 148.0 & 48.0 & 1 & 89.5 & 87.5 \\
TME 75 mg/kg i.p. $(\times 3)$ & $34.0^{* *}$ & 166.7 & 66.7 & 2 & 80.7 & 79.8 \\
TME 100 mg/kg i.p. $(\times 3)$ & $33.7^{* *}$ & 165.2 & 65.2 & 1 & 81.2 & 88.0 \\
\hline
\end{tabular}

${ }^{1}$ Number of animals that have survived over 60 days; N/A-not applicable; ${ }^{*}$ MST statistically significant (at $\left.\mathrm{p} \leq 0.01\right)$ vs. the untreated control: $\mathrm{p}=0.0002(37.5 \mathrm{mg} / \mathrm{kg}), \mathrm{p}=0.0044(75 \mathrm{mg} / \mathrm{kg}), \mathrm{p}=0.0105(100 \mathrm{mg} / \mathrm{kg})$ (log-rank test).

in order to allow identification of sub-fractions possessing biological activity. With the only exception of chloroform fractions CF3 and CF7 (Figure 1), all other fractions were devoid of cytotoxic activity (less than $20 \%$ inhibition at the highest concentration applied ( $300 \mu \mathrm{g} / \mathrm{ml})$; data not shown). Both active fractions however, were significantly less active as compared to the total methanolic extract of the plant, whereby the $I C_{50}$ values obtained were practically 10 times higher. Thus facing the obvious loss of activity upon fractionation the other pharmacological investigations (i.e. apoptosis detection and in vivo antineoplastic activity) were carried out with the parent methanolic extract.

A TLC analysis was conducted aiming to establish the chromatographic profile of the pharmacologically active crude extracts and its CF3 and CF7 fractions. The analysis of the active extracts showed zones of green color at retention factor (Rf) $0.12-0.13$ a blue zone at 0.31 and 0.23 , and pink areas at 0.44 $\mathrm{Rf}$ both in crude extract and in chloroform fractions CF3 and CF7. When the chromatogram was observed under ultraviolet light at $254 \mathrm{~nm}$, three absorption zones were observed with the following retention factor (Rf) $0.12,0.23,0.31$ and 0.44 , respectively. The chromatograms, after treatment with a $10 \%$
$\mathrm{KOH}$ methanolic solution - a well established spray reagent to detect quinones in the sample, showed brownish colored zones at $\mathrm{Rf} 0.23,0.31$ and 0.44 when observed under day light. These findings indicate the presence of quinone compounds. The ability of the total methanolic extract of Kigelia pinnata to induce apoptotic cell death was investigated by means of gel electrophoresis of DNA, extracted from the cytosolic fractions of SKW-3 after $24 \mathrm{~h}$ exposure at 75,150 or $300 \mu \mathrm{g} /$ $\mathrm{ml}$. The image obtained after DNA electrophoresis, ethidium bromide staining and UV-transillumination (Figure 1) shows the formations of detectable oligonucleosomal DNA laddering, indicative for execution of the apoptotic cascade.

The Kaplan-Meier survival curves and the corresponding values of the median survival time (MST) and increase in life span (ILS) are reported in Figure 2 and Table 2 respectively. The control mice exhibited a mean survival time of ca. 20 days. Evident from the results obtained the total methanolic extract from the stem bark of $K$. pinnata exerted strong antineoplastic activity in vivo, whereby the most prominent increase of the life span of treated animals (ca. $67 \%$ vs. the untreated control) was encountered at doses $75 \mathrm{mg} / \mathrm{kg}(66.67 \%$ vs. the untreated control) and $100 \mathrm{mg} / \mathrm{kg}$ (65.2 versus the untreated control). 
The tumor growth inhibition (calculated from the tumor size monitoring on days 6,10 and 14 after transplantation) was employed as a secondary end-point for the antineoplastic activity of the extract (Table 2, Figure 2). Statistically significant reduction in tumor size and volumes were found on days $10^{\text {th }}$ and $14^{\text {th }}$ all doses of the methanolic extract of the plant proved to hamper the enlargement of the tumor volume as compared to the untreated control, with TGI values ranging between ca. 80 and $90 \%$.

\section{Discussion}

This study was commenced in an attempt to elucidate some of the generally unexplored aspects of the oncopharmacological properties of Kigelia pinnata and more precisely its efficacy against in vitro models of hematologic malignancies on one hand, and its in vivo tumor-inhibiting potential, on the other. To meet this objective a detailed cytotoxicity screening was performed in a panel of eight tumor cell lines after $72 \mathrm{~h}$ exposure using the MTT-dye reduction assay as a read-out system and the $\mathrm{IC}_{50}$ as an end-point to evaluate efficacy. The proven cytotoxic activity of the methanolic extract further supported the earlier findings regarding the effects of $K$. pinnata dichloromethane, ethanol or water extracts against human cancer cells $[16,21,22]$. The results unambiguously indicate that the cell lines are chemosensitive to the components of the crude extract, even though with varying degree. Generally the $\mathrm{IC}_{50}$ values were within the range of those previously published $[13,20,22,41]$, albeit somewhat higher. These differences could be ascribed to the type of extract (e.g. fruit, bark, dichloromethane, ethanolic etc.) and to the peculiarities of the cell lines investigated. Much of the studies were focused on melanoma or other solid tumor-derived cell lines e.g. renal cell carcinoma [21], breast cancer [20], and colorectal carcinoma [33]. Nevertheless, the established difference in the chemosensitivity could not be solely ascribed to the cell type and origin of the models, but also to the experimental conditions employed. Thus most of the preceding studies used a substantially longer incubation period of $144 \mathrm{~h}$ [20-22] as compared to our experimental design with exposure for $72 \mathrm{~h}$. Considering the fact that in vitro studies by-pass nearly all pharmacokinetic processes it could be easily concluded that 6 days long exposure could not adequately mimic the in vivo situation. It is noteworthy in this context that the $\mathrm{NCl}$ guidelines for cytotoxicity screening recommend a $48 \mathrm{~h}$ incubation period [40].

In general, albeit the number of cell lines is limited for broad and definitive conclusions to be drawn out, the study has shown that the leukemia- and lymphoma derived cell lines are less sensitive to K. pinnata as compared to the solid tumor models (MCF-7 and Lewis lung), the only exception being the acute T-cell leukemia SKW-3. The observed chemosensitivity of the ER-positive breast cancer derived cell line MCF-7, also noted in previous studies with fruit extracts [20], warrants for more detailed evaluation regarding possible hormonal effects of the extract ingredients, especially having into consideration the anti-implantation activity of an ethanolic extract of $K$. pinnata [31] and the traditional utility of the plant to alleviate breast swelling, tenderness and pain [14], which are indicative for possible ER-modulating activity.

Our effort to perform a bioactivity-guided fractionation using column chromatography led to the isolation of ten pooled fractions. Among these however, only methanolic fractions CF 3 and CF7 retained biological activity, albeit sufficiently lower as compared to that of the crude extract. This well corroborates to the results from a previously described study whereby the fractionation of a highly cytotoxic chloroform extract of $K$. africana fruits was associated with a significant loss of activity in all of the nine obtained fractions. Even the most active fractions had their equitoxic $I C_{50}$ values shifted to substantially higher concentrations [22]. Although such detrimental effects of fractionation could be due to decomposition or oxidation of the putative active principles during the separation process, they could well be a consequence of pharmacological synergy between the different components of the parent crude extract $[41,42]$. In fact the cytotoxicity of $K$. africana has been regarded as a typical example of synergy between the individual active principles, a phenomenon well established for various medicinal plants [42].

The performed phytochemical study has shown that the tested extract contains quinoine species, to which its biological activity could be generally ascribed. Despite the immense pharmacological and phytochemical research on Kigelia pinnata the delineation of its real active principles remains elusive. Nevertheless, in general the anticancer and antiprotozoal activities have been attributed to the quinone compounds, especially the furanonaphtoquinoids characteristic for this species e.g. isopinnatal, kigelinole and isokigelinol, and kigelinone $[\mathbf{2 2}, \mathbf{2 3}, \mathbf{2 7}, \mathbf{4 3}]$, the latter being characterized as cytotoxic agent and identified in other plants used as traditional antineoplastic remedies $[16,44]$. Moreover, quinone structural fragment is found in some important anticancer drugs, or investigational cytotoxic agents including the anthracycline antibiotics, mitoxanthrone, aloeemodin, lapachol (an identified constituent of K. africana) $[21,35,45-48]$ etc.

Based on the lack of data regarding the mechanistic aspects of $K$. pinnata cytotoxicity we commenced a pharmacodynamic study on its ability to trigger oligonucleosomal DNAfragmentation - a key hallmark of apoptosis. The observed DNA-laddering after a short term exposure of SKW-3 cells to the tested extract indicates that the cytotoxic effects of the active principles are at least partly mediated by induction of programmed cell death (apoptosis). This has been identified as a major mechanism for the cytotoxic mode of action of otherwise chemically and pharmacologically distinct classes of plant-derived antineoplastic agents $[5,7,49]$. 
The tested methanolic extract exhibited prominent antineoplastic activity against Lewis lung carcinoma s.c. transplanted in BDF-1 mice. It significantly suppressed the tumor growth and more importantly was associated with increase in life span of all treated groups as compared to the untreated control. The lack of treatment-related mortality and the long-term survivors in all treatment groups is indicative for both antineoplastic efficacy in this tumor model and good tolerability within the tested dose range. To the best of our knowledge, this is the first report on the in vivo tumorinhibiting activity of $K$. pinnata extract.

\section{Conclusions}

Taken together our findings firmly indicate that $K$. pinnata stem bark extract is endowed by potent cytotoxic and antineoplastic effects, acting at least partly via apoptosis induction. Based on the in vitro studies and especially considering the observed in vivo tumor inhibiting potential of the plant it could be concluded that there is enormous scope for future detailed pharmacological as well as phytochemical investigations on $K$. africana as a natural source of potential antineoplastic agents.

\section{Competing interests}

The authors declare neither financial nor other competing interests.

\section{Authors' contributions}

DM carried out the phytochemical and pharmaceutical elaboration of the extract, participated in the bioactivityguided fractionation, prepared the extract formulation for the in vivo study and took central role for the preparation of the manuscript. IP participated in the phytochemical and analytical studies. GM participated in the in vivo and in vitro bioassay design and conduction. SK participated in the design of the in vivo and in vitro studies, coordinated the project and helped to draft the manuscript and to compile the discussion of the results. All authors read and approved the final manuscript. Publication history

Received: 22-May-2012 Revised: 16-June-2012

Accepted: 12-July-2012 Published: 19-Jly-2012

\section{References}

1. Srivastava V, Negi AS, Kumar JK, Gupta MM, Khanuja SP: Plant-based anticancer molecules: a chemical and biological profile of some important leads. Bioorg Med Chem 2005; 13;(21.);5892-908. | Article | PubMed

2. Wang $\mathrm{HK}$, Plant-derived anticancer agents currently in clinical use or in clinical trials, IDrugs 1998, 1: 92-102. | PubMed

3. Chabner BA, Amrein PC, Druker BJ, et al., Chemotherapy of neoplastic disease. In: Goodman \& Gilman's The pharmacological basis of therapeutics. Edited by L.L. Brunton, J.S. Lazo and K.L. Parker. New York, McGraw Hill 2006, 1315 - 1403. | Book

4. Cragg GM, Newman DJ: Antineoplastic agents from natural sources: achievements and future directions. Expert Opin Investig Drugs 2000; 9;(12.);2783-97. | Article | PubMed

5. Cragg GM, Grothaus PG, Newman DJ: Impact of natural prod- ucts on developing new anti-cancer agents. Chem Rev 2009; 109;(7.);3012-43. | Article | PubMed

6. Cragg GM, Newman DJ: Plants as a source of anti-cancer agents. Journal of Ethnopharmacology 2005; 100;(1-2.);72-9. I Article

7. Dewick PM, Tumour inhibitors from plants. In: Trease and Evans Pharmacognosy. Edited by W.C. Evans. Edinburgh, Saunders 2005, 394-406.

8. Patrick G, An Introduction to Medicinal Chemistry, Oxford University Press, New York 2005.

9. Cragg GM, Newman DJ: Discovery and development of antineoplastic agents from natural sources. Cancer Invest 1999; 17;(2.);153-63. | Article | PubMed

10. Newman DJ, Cragg GM: Natural product scaffolds as leads to drugs. Future Med Chem 2009; 1;(8.);1415-27. | Article | PubMed

11. Houghton PJ, Traditional plant medicines as a source of new drugs. In: Trease and Evans Pharmacognosy. Edited by W.C. Evans. Edinburgh, Saunders 2005, 125-134.

12. O'Neil MJ,Lewis JA, Plant products and high throughput screening. In: Trease and Evans Pharmacognosy. Edited by W.C. Evans. Edinburgh, Saunders 2005, 109-114.

13. Houghton PJ, The sausage tree (Kigelia pinnata): Ethnobotany and recent scientific work. South Afr J Botany 2002, 68: 14-20. Article

14. Gabriel OA,Olubunmi A, Comprehensive scientific demystification of Kigelia africana: A review. Afr J Pure Appl Chem 2009, 3: 158-164. | Article

15. William Carey M, Rao NV, Kumar BR, Mohan GK: Anti-inflammatory and analgesic activities of methanolic extract of Kigelia pinnata DC flower. J Ethnopharmacol 2010; 130;(1.);179-82. | Article | PubMed

16. Saini S, Kaur H, Verma B, et al., Kigellia africana (Lin) Benth - An overview. Nat Prod Rad 2009, 8: 190-197. | PubMed

17. Akunyili DN, Houghton PJ, Raman A: Antimicrobial activities of the stembark of Kigelia pinnata. J Ethnopharmacol 1991; 35;(2.);173-7. I Article | PubMed

18. Gouda YG, Abdel-baky AM, Darwish FM, Mohamed KM, Kasai R, Yamasaki K: Iridoids from Kigelia pinnata DC. fruits. Phytochemistry 2003; 63;(8.);887-92. | Article | PubMed

19. Picerno P, Autore G, Marzocco S, Meloni M, Sanogo R, Aquino RP Anti-inflammatory activity of verminoside from Kigelia africana and evaluation of cutaneous irritation in cell cultures and reconstituted human epidermis. J Nat Prod 2005; 68;(11.);1610-4. | Article | PubMed

20. Higgins CA, Bell T, Delbederi Z, Feutren-Burton S, McClean B, O'Dowd C, et al.: Growth inhibitory activity of extracted material and isolated compounds from the fruits of Kigelia pinnata. Planta Med 2010; 76;(16.);1840-6. | Article | PubMed

21. Houghton PJ, Photiou A, Uddin S, Shah P, Browning M, Jackson SJ, et al.: Activity of extracts of Kigelia pinnata against melanoma and renal carcinoma cell lines. Planta Med 1994; 60;(5.);430-3. | Article | PubMed

22. Jackson SJ, Houghton PJ, Retsas S, Photiou A: In vitro cytotoxicity of norviburtinal and isopinnatal from Kigelia pinnata against cancer cell lines. Planta Med 2000; 66;(8.);758-61. | Article | PubMed

23. Moideen SV, Houghton PJ, Rock P, Croft SL, Aboagye-Nyame F: 
Activity of extracts and naphthoquinones from Kigelia pinnata against Trypanosoma brucei brucei and Trypanosoma brucei rhodesiense. Planta Med 1999; 65;(6.);536-40. | Article | PubMed

24. Binutu OA, Adesogan KE, Okogun JI: Antibacterial and antifungal compounds from Kigelia pinnata. Planta Med 1996; 62;(4.);352-3. | Article | PubMed

25. Gouda YG, Abdel-Baky AM, Mohamed KM, Darwish FM, Kasai $\mathrm{R}$, Yamasaki K: Phenylpropanoid and phenylethanoid derivatives from Kigelia pinnata DC. fruits. Nat Prod Res 2006; 20;(10.);935-9. | Article | PubMed

26. Msouthi JD,Mangombo D, Medicinal herbs in Malawi and their uses, Hamdard 1983, 26: 94-100.

27. Weiss CR, Moideen SV, Croft SL, Houghton PJ: Activity of extracts and isolated naphthoquinones from Kigelia pinnata against Plasmodium falciparum. J Nat Prod 2000; 63;(9.);13069. | Article | PubMed

28. Zofou D, Kengne AB, Tene M, Ngemenya MN, Tane P, Titanji VP: In vitro antiplasmodial activity and cytotoxicity of crude extracts and compounds from the stem bark of Kigelia africana (Lam.) Benth (Bignoniaceae). Parasitol Res 2011; 108;(6.);1383-90. | Article | PubMed

29. Zofou D, Tene M, Tane P, Titanji VP: Antimalarial drug interactions of compounds isolated from Kigelia africana (Bignoniaceae) and their synergism with artemether, against the multidrug-resistant W2mef Plasmodium falciparum strain. Parasitol Res 2012; 110;(2.);539-44. | Article | PubMed

30. Olaleye MT, Rocha BT: Acetaminophen-induced liver damage in mice: effects of some medicinal plants on the oxidative defense system. Exp Toxicol Pathol 2008; 59;(5.);319-27. I Article I PubMed

31. Prakash AO, Saxena V, Shukla S, Tewari RK, Mathur S, Gupta A, et al.: Anti-implantation activity of some indigenous plants in rats. Acta Eur Fertil 1985; 16;(6.);441-8. I PubMed

32. Khan MF, Dixit P, Jaiswal N, Tamrakar AK, Srivastava AK, Maurya $\mathrm{R}$ : Chemical constituents of Kigelia pinnata twigs and their GLUT4 translocation modulatory effect in skeletal muscle cells. Fitoterapia 2012; 83;(1.);125-9. | Article | PubMed

33. Chivandi E, Cave E, Davidson BC, Erlwanger KH, Moyo D, Madziva MT: Suppression of Caco-2 and HEK-293 cell proliferation by Kigelia africana, Mimusops zeyheri and Ximenia caffra seed oils. In Vivo 2012; 26;(1.);99-105. I Article | PubMed

34. Balassiano IT, De Paulo SA, Henriques Silva N, Cabral MC, da Gloria da Costa Carvalho M: Demonstration of the lapachol as a potential drug for reducing cancer metastasis. Oncol Rep 2005; 13;(2.);329-33. | Article | PubMed

35. Rao KV: Quinone natural products: streptonigrin (NSC-45383) and lapachol (NSC-11905) structure-activity relationships. Cancer Chemother Rep 2 1974; 4;(4.);11-7. I PubMed

36. Wagner $\mathrm{H}$,Bladt $\mathrm{S}$, Plant drug analysis: $\mathbf{A}$ thin layer chromatography atlas. Springer; New York/Heidelberg 2001. I Book

37. Mosmann T: Rapid colorimetric assay for cellular growth and survival: application to proliferation and cytotoxicity assays. $J$ Immunol Methods 1983; 65;(1-2.);55-63. I Article I PubMed

38. Konstantinov SM, Eibl H, Berger MR: BCR-ABL influences the antileukaemic efficacy of alkylphosphocholines. Br J Haematol 1999; 107;(2.);365-80. | Article | PubMed

39. Sofiina ZP, Syrkin AB, Goldin A, et al., Editors, Experimental evaluation of anti-tunour drugs in the USSR and in the USA, Moscow, Meditsina 1980.

40. Voskoglou-Nomikos T, Pater JL, Seymour L: Clinical predictive value of the in vitro cell line, human xenograft, and mouse allograft preclinical cancer models. Clin Cancer Res 2003; 9;(11.);4227-39. | Article | PubMed

41. Houghton PJ, Howes MJ, Lee CC, Steventon G: Uses and abuses of in vitro tests in ethnopharmacology: visualizing an elephant. J Ethnopharmacol 2007; 110;(3.);391-400. | Article I PubMed

42. Heinrich M, Barnes J, Gibbons S, et al., Fundamentals of Pharmacognosy and Phytotherapy, Churchill Livingstone, Edinburgh (2004). I Book

43. Hirai KI, Koyama J, Pan J, Simamura E, Shimada H, Yamori T, et al.: Furanonaphthoquinone analogs possessing preferential antitumor activity compared to normal cells. Cancer Detect Prev 1999; 23;(6.);539-50. I PubMed

44. Rao MM, Kingston DG: Plant anticancer agents. XII. Isolation and structure elucidation of new cytotoxic quinones from Tabebuia cassinoides. J Nat Prod 1982; 45;(5.);600-4. | PubMed

45. Koyama J, Morita I, Yamori T: Correlation between cytotoxic activities and reduction potentials of heterocyclic quinones. Molecules 2010; 15;(9.);6559-69. | Article | PubMed

46. Burnett AR,Thomson RH, Lapachol, Chem Ind 1968, 50: 1771.

47. Srinivas G, Anto RJ, Srinivas P, Vidhyalakshmi S, Senan VP, Karunagaran D: Emodin induces apoptosis of human cervical cancer cells through poly(ADP-ribose) polymerase cleavage and activation of caspase-9. Eur J Pharmacol 2003; 473;(2-3.);117-25. । Article I PubMed

48. Srinivas G, Babykutty S, Sathiadevan PP, Srinivas P: Molecular mechanism of emodin action: transition from laxative ingredient to an antitumor agent. Med Res Rev 2007; 27;(5.);591-608. | Article | PubMed

49. Wahle KW, Brown I, Rotondo D, Heys SD: Plant phenolics in the prevention and treatment of cancer. Adv Exp Med Biol 2010; 698;(36-51. | Article | PubMed 